Marjan HOČEVAR*

\title{
"NA DELU, DOMA«: UČINKI PANDEMIJE COVIDA-19 NA PROSTORSKO-ČASOVNO ORGANIZACIJO DOMA IN DELA**
}

\begin{abstract}
Povzetek. VČlanku smo konceptualno obravnavali spremembe pri organiziranju življenjskih sfer doma (bivanja) in dela (delovnega mesta) z vidika vsakodnevnih praks $v$ časouno-prostorski perspektivi. Izhajali smo iz klasične sociološke dileme o mehanizmih diferenciacije in integracije. Zastavljeno raziskovalno vprašanje je, ali pandemija Covida-19 ob potencirani tehnološki mediaciji pospeši proces dediferenciacije sfer doma in dela. V analizi smo ugotovili protislovne učinke tega procesa, zlasti problematično vzpostavljanje zasebnosti doma kot sidrišča vseh aktivnosti. Manifestacija sidriščnosti doma je domocentričnost, ki jo povezujemo s tradicionalnimi, predindustrijskimi oblikami družbenoprostorske integracije homogenih, nediferenciranih življenjskih sfer. Te potencialno trajnejše premike pojasnimo kot regresiune.
\end{abstract}

Ključni pojmi: prostor/čas, dediferenciacija, življenjske sfere, dom/delo

\section{Uvod}

Pandemijo Covida-19 je zaradi obsega in trajanja (vseprisotnosti) mogoče označiti za pojav s potencialnimi učinki na družbene spremembe, zlasti na pospeševanje sociotehničnih tranzicij v teku. Začasna, občasna in mestoma radikalna regulacija fizičnega gibanja (mobilnosti) spreminja prostorsko, vendar še izraziteje poudarjeno, časovno organiziranost akterjev. Nova organiziranost se nanaša na prakse bivanja, dela, združevanja, produkcijo in druge vsakodnevne prakse. Daljše kot je trajanje pojava, večja je verjetnost, da začasni načini organiziranja znotraj sfer vsakdanjega življenja pridobijo normativni značaj trajnejših rutiniziranih praks z logiko procesu alnosti (Avelino in Rotmans, 2009; Schatzki, 2020).

\footnotetext{
* Dr. Marjan Hočevar, izredni profesor, Fakulteta za družbene vede, Univerza v Ljubljani, Slovenija.

** Izvirni znanstveni članek. DOI: $10.51936 /$ tip. $58.3 .719-743$
} 
Potencialno se krepi ali »utirja« spremenjena institucionalna normativnost dela in doma. Pandemija nakazuje pospešeno dinamiko združevanja sfere dela in bivanja, zlasti njunega prežemanja v časovno-prostorski perspektivi. Obenem je ta pojav priložnost za prevetritev spoznavne teže dosedanjih konceptov družbene preobrazbe. Spodbuja razmislek o temeljnih protislovjih v dolgoročnejših procesih spreminjanja vzorcev diferenciacije in integracije, ločevanja in združevanja ter bližine in oddaljenosti na vseh ravneh družbeno-prostorske organiziranosti.

V članku se konceptualno osredinimo na obravnavo spremenjenega organiziranja bivanja (doma, stanovanja, zasebnosti) in dela (delovnega mesta, službe, javnega) v kontekstu dveh razsežnosti, prostora in časa. V grobem - s kritičnimi pomisleki - izhajamo iz modernistične teoretske perspektive o regularnosti in predvidljivosti procesualnih ter relacijskih zakonitostih družbenih sprememb. Naslanjamo se na dialektično razumevanje protislovnih procesov osamosvajanja in povezovanja (Mlinar, 1978) ter logiko regularnosti sociotehničnih tranzicij (Geels, 2002; Sorrel, 2018). Pandemijo Covida-19 obravnavamo kot emergentni dogodek ali epizodo, ki pospešuje, sproža ali prekinja rutinizirane prakse in je lahko vezni člen med specifičnimi mikro- in splošnimi makroskopskimi dejavniki tranzicij 720 (Schlüter in dr., 2018; Mosleh in Larsen, 2020).

Osnovna teza, ki jo razvijamo, je, da pandemija pospeši in utrjuje že utečen proces dediferenciacije življenjskih sfer s proizvajanjem protislovnih učinkov na družbeno integracijo v času in prostoru. Pandemija bolj kot prostorsko izostri časovno razsežnost "pospeševanja družbe« (Rosa, 2017; Meynhardt, 2021). Ključna je organizacija »časovnega proračuna« vsakodnevnih življenjskih praks na eni prostorski lokaciji - na domu, kar lahko omogoča ali omejuje avtonomne strategije umika iz zasebnosti doma (opting-out). Identificiramo nekaj značilnih nasprotnosmernih teženj in trenj v dinamiki pospešenega združevanja sfere doma (zasebnega življenja) s sfero dela (javnim življenjem). Ugotavljamo, da prežemanje obeh sfer načeloma lahko krepi emancipacijo in avtonomno delovanje akterjev ob vzpostavljanju prožnejših mehanizmov povezovanja. Po drugi strani ima prežemanje (tudi zamegljevanje) obeh sfer, ob pospešeni tehnološki mediaciji, lahko nasprotne učinke v krepitvi retrogradne domačijske avtarkije. Morebitni retrogradni učinki lahko vključujejo ponovno vzpostavljanje hierarhičnih mehanizmov nadzorovanja, prisile in odvisnosti z vzpostavljanjem retradicionalizacije družbenih vlog ter hierarhije položajev, kar lahko vodi k predmoderni družbeni integraciji. 


\section{Življenjske sfere na oseh čas/prostor}

V tej konceptualni razpravi skušamo povezati deskriptivno naravo geografije prostora in časa $\mathrm{z}$ analitičnim, abstraktnejšim zajemanjem procesov dediferenciacije v sociologiji. Pandemijo Covid-19 obravnavamo kot emergentni dogodek s potencialnimi vplivi na pospeševanje teh procesov. Združujemo aksialno obravnavo dediferenciacije, to je spremljanje dinamike na oseh čas/prostor s sferično obravnavo, to je spremljanje razmejevanja, prekrivanja, prepletanja ali prežemanja življenjskih domen ali sfer. ${ }^{1}$ Gre za medsebojni vpliv strnjenosti ali razpršenosti dejavnosti v prostoru/času glede na bližino ali oddaljenost oz. dostopnost do sidrišč (lokacij, "postaj«) in ločenosti ali povezanosti posamičnih življenjskih sfer (zadev, praks). Visoka raven časovno-prostorske dostopnosti in neovirana prehodnost $v$ fizičnem ali virtualnem okolju zmanjšuje specifično težo središčnosti ali sidrne vloge območja posamične življenjske sfere. ${ }^{2}$

Življenjske sfere so bile v obdobju industrijske modernosti z različnimi mehanizmi institucionalne regulacije in samoregulacije akterjev jasneje, bolj togo razmejene. Relativna ločenost sfer je temeljila na visoki stopnji delitve dela na ločenih lokacijah ob normiranih časovnih sekvencah. Ločenost sfer je bil en od ključnih mehanizmov vzpostavitve avtonomije funkcionalnih podsistemov. To dinamiko je spremljala analogna (npr. transportna) tehnološka mediacija družbenih razmerij, ustaljenost časovno-prostorskih poti v coniranem grajenem okolju z ovirami v dostopnosti ter dosegljivosti pri povezovanju oz. komuniciranju.

Sociotehnična tranzicija z visoko vsebovanostjo (visoko)tehnološke mediacije (Sorrell, 2018) z vgrajeno informacijsko omreženostjo v postindustrijskem obdobju pa, nasprotno, simultano povzroča erozijo meja med sferami in akterjem omogoča (ali jih sili v) bolj avtonomno upravljanje razmerij in aktivnosti. Časovno-prostorske konfiguracije postajajo vse bolj kompleksne, vključno z »izničenjem razdalje« z načelom ubikvitarnosti. Tehnologije, zlasti informacijske in telekomunikacijske, v dialektiko avtonomije in povezovanja vnašajo dodatno dimenzijo, ki je več kot tehnična. Tehnologije niso več le nevtralna orodja za dosegljivost ciljev, temveč so hkrati samodejni vmesniki, aktivatorji in aktivni sooblikovalci - "aktanti Življenjskega okolja akterjev (Latour, 1993; Latour v Watts, 2020). Takšna

1 V širšem, historično-civilizacijskem kontekstu se je s pojasnjevalno težo aksialnosti in sfer vplivanja ukvarjal S. N. Esenstadt (v: A. K. Giri, 2011). V časovno-prostorskem kontekstu aksialnost in sferičnost združuje geografski koncept časovno-prostorske prizme po izvorni zasnovi T. Heagerstranda (1970). (V: P. Merriman, 2012.)

2 Webrovo zasnovo ločenih, zgodovinsko razvijajočih se sfer življenja kot analitičnega pripomočka za pojasnjevanje družbenih formacij in oblikovanja območij vpliva vrednotnih ter normativnih vzorcev je mogoče aplicirati na ravni praks akterjev. Podrobneje v: S. Terpe, 2020. 
časovno-prostorska dinamika vsakodnevnih praks predpostavlja premike v sposobnosti obvladovanja ravnotežja med predhodno bolj razmejenimi sferami javnega in zasebnega, domačega in profesionalnega ter formalnega in neformalnega (ang. life-work balance, work-life conlict). ${ }^{3}$

Poudarjen značaj tehnološke mediacije v času pandemije Covida-19 je priložnost za globlji razmislek o smiselni povezavi najbolj abstraktnih vprašanj ontologije družbenega $\mathrm{z}$ najbolj konkretnimi praksami vsakdanjosti v časovno-prostorski perspektivi. Premike od ločenosti k prežemanju življenjskih sfer lahko upoštevamo:

- kot hevristični pripomoček za razumevanje dolgoročnejših, strukturnih oz. sistemskih procesov v dialektiki osamosvajanja (diferenciacije) in povezovanja (integracije);

- kot opazovanje spreminjanja ali rekonstrukcije vzorcev vsakodnevnih rutinskih praks v življenju ljudi, ko organizacija časa in prostora postane bolj prožna in razdrobljena.

\section{Dediferenciacija življenjskih sfer}

Dediferenciacijo v izhodišču obravnavamo kot družbene premike k nerazločljivosti, razsidriščenju, prežemanju in prekrivanju življenjskih sfer vsakdanjega življenja pod vplivom »časovno-prostorskega krčenja» oz. »konvergence časa in prostora" (Harvey, 1990), ko ni več jasne povezave med dejavnostmi, krajem in časom. Dimenziji prostora in časa vse manj določata omejitve ter ovire o tem, kje in kdaj se kaj dogaja.

Pandemija Covida-19 je izziv za ponovni razmislek o predpostavki, da vse manjša določljivost obeh dimenzij omogoča progresivno regularnost osamosvajanja in povezovanja (Mlinar, 1994, 2008a). Začasno in potencialno trajnejše vračanje v sidriščnost doma ni le mehanična domena časovno-prostorskega organiziranja dejavnosti v kontekstu upravljanja s časovno-prostorskimi potmi. Sidriščnost zadeva vprašanje homo- ali heteronomnega osmišljanja življenjskih sfer (npr. javno/zasebno, formalno/neformalno), strnjenih znotraj ali razpršenih zunaj bivanjske sfere doma. Ob začasni ujetosti v eno sidrišče je vredno razmisliti o potencialni rutinizaciji te prakse po pandemiji Covida-19, v smeri regresije avtonomije in homogenizirane integracije $-\mathrm{v}$ domocentričnost.

Pri opredeljevanju koncepta, dediferenciacijo kot proces ali pojavno obliko procesa lahko v grobem umestimo v dve sociološki perspektivi, sistemsko in neo-durkheimovsko, ob eklektičnih (postmodernih) pojmovanjih,

3 Preučevanje teme ravnotežja med delom in zasebnim življenjem (work-life balance - WLB) je že vrsto let samostojna tema raziskovanja v organizacijskih študijah, študijah dela, stanovanja, družine, spolov, konstrukcije identitet in na številnih drugih področjih (glej pregled konceptov v: F. R. Khateeb, 2021). 
ki so kombinacija obeh (West, 2007; Schatzki, 2020). V sistemski perspektivi se dediferenciacija nanaša na povratne, nasprotnosmerne procese, ko se že funkcionalno specializirani in avtonomni načini organiziranja, strukturiranosti ter normativnosti vračajo $\mathrm{v}$ enostavnejše oblike. $\mathrm{S}$ te perspektive je dediferenciacija sama po sebi negativna ali celo "patološka». V neo-durkheimovski perspektivi ${ }^{4}$ se dediferenciacija nanaša na spremenjeno naravo družbenih vezi in identitet $\mathrm{v}$ sferah kulture, ekonomije in politike $\mathrm{z}$ emancipacijskim potencialom reorganiziranih načinov družbene solidarnosti. Ta perspektiva je $\mathrm{v}$ izhodišču afirmativna.

Obe perspektivi sta prisotni v prostorskih študijah ter v vse številčnejših študijah časa, poudarjeno tudi v času pandemije Covida-19 (Adam, 2013; Ward, 2020; Meynhardt, 2021). V kontekstu naše razprave je instrumentalno zlasti tematiziranje dediferenciacije v geografiji, znotraj koncepta časovne geografije (time/space geography), ki predstavlja tudi sicer enega bolj nazornih primerov interdisciplinarnosti v družboslovju.

\section{Diferenciacija in integracija $v$ sistemski perspektivi}

Spreminjanje dinamike življenjskih sfer $\mathrm{v}$ časovno-prostorski perspektivi predpostavlja osredotočenje na morebitne premike v ločenih ali povezanih razpravah o družbenih procesih (temporalnosti), relacijah (prostorjenju) in domenah (praksah). Sistemska perspektiva dediferenciacije podsistemov je izrazito abstraktna. Lahko je pomemben hevristični pripomoček, zlasti za obravnavo procesualne teže in učinkov konkretnih dogodkov, emergenc ali epizod, za kontekstualizacijo dolgoročnejših sprememb. Epizode (v času) imajo $\mathrm{v}$ »uhmannovski« perspektivi pomen evolucijskega mehanizma, s pomočjo katerega lahko sistem začasno zaustavi svojo rutinsko dinamiko in tako sproži "samorazmislek" o prilagoditvenih spremembah (Overwijk, 2021). Te spremembe omogočajo nadaljnjo komunikativno kompleksnost družbenega sistema $v$ novih okvirih diferenciacije in integracije. Tako razumljena dediferenciacija dopušča tudi različne "nesistemske» interpretacije v dinamiki regresij in razvoja razmerja med sferama doma in dela.

Za interpretativno opazovanje potencialnih učinkov pandemičnih praks na siceršnjo in v času pandemije Covida-19 pospešeno dediferenciacijo življenjskih sfer, so indikativna nasprotujoča teoretiziranja o regresiji avtonomij podsistemov. Postulat, da se družbeni sistemi diferencirajo in s tem razvijajo le, če medsebojno in z okoljem avtonomno komunicirajo tudi v razmerah izrednih epizod oz. dogodkov (Luhmann, 1995), je podlaga več pandemskih tematiziranj znotraj okvirov sistemske teorije ali z naslanjanjem nanjo

4 Nekateri avtorji povezujejo ali zamenjujejo neo-durkheimovsko in neo-marksistično perspektivo. V: S. K. Sanderson, 2015. 
(Meynhardt, 2021; Pires in dr., 2021). Nasprotujoči argumenti v razpravah izhajajo $\mathrm{v}$ grobem iz različne obravnave mehanizmov diferenciacije in integracije ter upravljanja s kompleksnostjo oz. njene redukcije. Na eni strani prevladuje argument, da pandemične razmere nujno zahtevajo redukcijo kompleksnosti družbe v prid integracije. Nujno zmanjševanje avtonomije podsistemov v času pandemije Covida-19, npr. zdravstvenega in ekonomskega, ima tako lahko trajnejše posledice $\mathrm{v}$ smeri bolj homogene ali retrogradne integracije družbe (Basaure in dr., 2021). Na drugi strani izstopa argument, da je $\mathrm{v}$ teh razmerah neizbežna redukcija kompleksnosti lahko dosežena zgolj ali prav z ohranjanjem visoke avtonomije podsistemov, vendar s prilagojenimi načini komuniciranja med njimi in njihovimi oko1ji. Zmanjševanje avtonomij bi tudi dolgoročno vodilo v regresivne oblike družbene integracije (Esposito, 2020; Rufino, 2020). Ta argument bomo v nadaljevanju, ob obravnavi sfer doma in dela umestili $\mathrm{v}$ tezo o retrogradnih učinkih dediferenciacije po obdobju pandemije Covida-19.

\section{Diferenciacija in integracija v neo-durkheimovski perspektivi}

Čeprav je mogoče idejo, da se družba spreminja v procesu institucionalne 724 specializacije zaslediti že $v$ antični filozofiji, se je sodobna teorija družbenih sprememb kot diferenciacija in integracija začela z Emilom Durkheimom in njegovo razlago delitve dela ter tipi solidarnosti (Delanty, 2013; Alexander, 2018). Naslavljanje izvornega problema, da proces diferenciacije (lahko) povzroča "patologije« pri integraciji družbe, je bila osrednja tema večine modernizacijskih, evolucionističnih in razvojnih teorij. Diferenciacija je v grobem cena modernizacije $\mathrm{z}$ različnimi poudarki afirmacije, kritike ali dialektike njene procesualne logike $\mathrm{v}$ različnih manifestnih napetostih (Hočevar, 2018). Te so npr.: moralni individualizem, razdrobljenost življenjskih sfer in rutinizacija družbenih vlog, integracija zapletenih institucionalnih vzorcev itd. Interpretacije modernizacijskega »odraščanja in pozne refleksivne modernosti, tudi z oznakami neo- ali postmodernisti, vključujejo dediferenciacijo v svojo pojasnjevalno shemo na različne načine. Lahko je hevristični pripomoček ali vzporedni mehanizem obvladovanja kompleksnosti z vidika institucij. $Z$ vidika emancipacije in refleksivne mobilizacije akterjev je dediferenciacija nujno dopolnilo, blažilec diferenciacije, zato ne gre za atavizem, retrogradnost, nelogično napako ali patološko lastnost modernosti.

Najočitnejše dejstvo pandemične situacije je prekinitev običajnega delovanja delitve dela s prekinitvijo rutinirane socialne soodvisnosti in koordinacije. Manj očitna sta pomanjkanje spontanosti in kontinuitete $\mathrm{v}$ družbenih funkcijah ter vloga »običajne« solidarnosti v zvezi s tem. Razprave znotraj te sicer izrazito raznolike perspektive gredo $\mathrm{v}$ dve smeri. Na eni strani prevladujejo domneve, da pandemija Covida-19 nakazuje možnosti hibridizacije 
tradicionalne in sodobne solidarnosti s preoblikovanjem razmerja med doseženo avtonomijo in ohlapno integracijo, na ravni akterjev in družbe (Basaure in dr., 2021). Na drugi strani izstopajo opozarjanja o refiguraciji neenakosti ter preurejanju vzvodov moči, ki lahko nakazuje prevlado tradicionalne nad sodobno solidarnostjo (Werron in Ringel, 2020). Obe smeri tematiziranj bomo v nadaljevanju umestili v razpravo o razmerju med sferama doma in dela.

\section{Stara in nova geografija časa}

Za obravnavo dediferenciacije sfer doma in dela v nadaljevanju so uporabni vpogledi v bolj usmerjena disciplinarna področja raziskovanja pred pandemijo Covida-19, ki tematiko obravnavajo v časovno-prostorskem kontekstu. Indikativna so tematiziranja o prežemanju življenjskih sfer znotraj organizacijskih, komunikacijskih, časovnih, geografskih, turističnih ter mobilnostnih študij (Sheller in Urry, 2003; Susen, 2011; Klegg in van Iterson, 2013; Cohen in dr., 2016; Hočevar in Bartol, 2021). Konkretne družbene prakse, tako individualne kot kolektivne, ki se med pandemijo vzpostavijo, reproducirajo, nadgradijo, povežejo, odklopijo, institucionalizirajo ali deinstitucionalizirajo, torej lahko služijo tudi kot retrospektivna evidenca splošnih socioloških konceptov "metapraks« (Werron in Ringel, 2020) ali razvojnih procesov (Teune in Mlinar, 1978; Mlinar, 1994, 2008a).

V zadnjih desetletjih prevladuje konceptualno naziranje o vzročnosti postopnega časovno-prostorskega krčenja in proženja družbenih razmerij ob naraščajoči tehnološki mediaciji v dostopnosti do povezav (Harvey, 1990; Latour, 1993; Castells, 1996; Sorrell, 2018 ). Tako imenovani "prostorski obrat« in nato še »časovni obrat" v sociologiji (Urry, 2000; Bauman, 2000; Adam, 2013; Rosa, 2017) sta bila močno navdahnjena z »analognim« geografskim konceptom časovno-prostorskih poti ali časovno geografijo v zgodnjih sedemdesetih letih prejšnjega stoletja (Hägerstrand, 1970). Ta preprost, teoretsko precej neartikuliran koncept je sociologom ob prihajajoči informacijski in telekomunikacijski revoluciji asistiral pri zasnovi teze o refleksivni modernosti (Giddens, 1984; Beck, 1992; Bauman, 2000). Sociologi so med drugim postali nepogrešljivi miselni motorji pri bolj deskriptivnem uokvirjanju povezanosti preobrazbe grajenega okolja s spremembami družbenoprostorske organiziranosti. Predhodna klasična sociološka tematiziranja razmerij med socialno in prostorsko bližino ali oddaljenostjo ter strnjenostjo in razpršenostjo interakcij (npr. Park in dr., 1925; Sorokin, 1943)5 so postala integralni del prostorske stroke in akademskih tematiziranj fizičnega prostora, zlasti organizacije grajenega prostora naselij.

\footnotetext{
5 Za analitični pregled „geo-sociološke« imaginacije glej v: J. R. Porter, 2011
} 
Časovna geografija je ob nastanku, v razmerah industrijskega kapitalizma, temeljila na pojasnjevanju mehanizmov premikanja ljudi v fizičnem (še ne virtualnem) prostoru ter na takrat še jasni ločenosti plačanega oz. produktivnega dela in bivanja. Na eni strani premikanje v eni časovni enoti (dnevu, tednu, življenju) temelji na posameznikovih potrebah ali željah, na drugi strani pa na soočanju z nizom časovno-prostorskih omejitev. Te omejitve določajo prostorsko dostopnost in mobilnost (Tietze in Musson, 2002). V kontekstu klasične družbene organiziranosti sta prostor in čas hkrati ovirala višjo stopnjo individualne avtonomije in vzdrževala družbeno integracijo s funkcionalno diferenciacijo.

Temeljna predpostavka, v kontekstu klasične časovne geografije, je, da so posameznikovi načrti časovno-prostorskih poti nujno podvrženi omejitvam »časovnih proračunov«, ki mu jih nalagajo fiksne obveznosti ali rutinirane dejavnosti. Te so razporejene na različnih časovno-prostorskih lokacijah, postajah ali sidriščih (glej sliko 1). Delovna mesta (službeni prostori) in urniki plačanega dela so glavna sidrišča v celotnem vzorcu vsakodnevnih praks. Povezave v neformalnih, nedelovnih sferah bivanja in premikanje v domačem (prostem) prostoru/času je podrejeno formalni sferi produktivnega dela, skladno z logiko organizacije grajenega prostora naselij s spre-

726 mljajočo infrastrukturo za premikanje (dostopnost) v prostoru.

\section{Tabela 1: ČASOVNO-PROSTORSKE POTI}

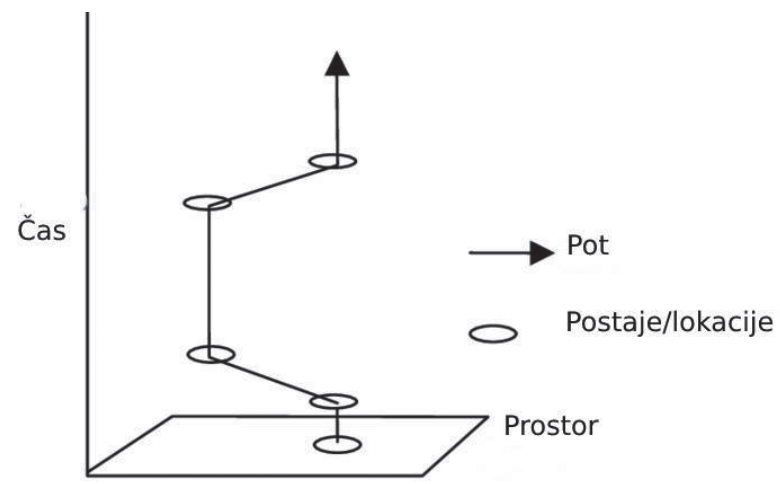

Vir: prirejeno po S. A. Rye, 2008.

Najprej postopen in nato pospešen prehod iz navidezno preproste analogne mehanike premikanja $\mathrm{v}$ času in prostoru $\mathrm{v}$ kompleksno digitalno mreženje življenjskih sfer s sinhrono in asinhrono teleprisotnostjo temeljito premeša pojasnjevalne karte v »igri ničelnih vsot« (Janelle, 1993). Ne velja več pravilo o povezavi prostorskih s časovnimi potmi. Zmanjševanje števila prostorskih poti s fiksnimi sidrišči (postajami ali lokacijami) omogoča bolj 
racionalno upravljanje zadev s časom. Zadeve ali opravki niso več vezani na lokacijo, vse manj pa tudi na čas. »Motnje«v organizaciji prej jasnih časovnih zaporedij in razmejenih prostorov so pomenile smiselno vzpodbudo različnim konceptualnim zamislim o povečevanju avtonomij pri povezovanju ljudi. ${ }^{6}$ Ideja sploščanja celotnega spektra hierarhij, s prežemanjem življenjskih sfer ter v njihovi deinstitucionalizaciji, je v jedru pojasnjevalne razvojne logike družbenih sistemov, znotraj bolj premočrtnih konceptov družbene evolucije in pri različicah sistemske teorije. ${ }^{7}$ Obet zmanjševanja odtujenosti dela ob instrumentalni (zabojniški) vlogi doma, kakršnega je imel v obdobju industrijske modernosti, je predstavljal močnejši pojasnjevalni potencial kot sočasno opozarjanje kritikov o "zamegljevanju« novih oblik neenakosti ter odvisnosti ob pospešeni ubikvitarni omreženosti v postindustrijski modernosti.

Pojav pandemije Covida-19 vzpodbuja sicer že dalj časa potekajoče razprave o novi časovni geografiji, tako glede morebitnih dolgoročnejših učinkov na transformacijo časovno-prostorske organizacije kot učinkov na mehanizme strukturacije (Knoblauch in Löw, 2020; Schatzki, 2020). Sedanji poudarek je v še nejasnem razmerju med »zabojniško« in relacijsko vlogo (fizičnega in virtualnega) prostora pri upravljanju s časom. Iz tega sklepamo, da se poraja potreba o morebitni, vsaj preliminarni dopolnjeni shemi treh zaporednih razvojnih (ali evolucijskih) faz v historični dinamiki povezovanja ter ločevanja sfer doma in dela, bodisi z rekonstrukcijo tretje bodisi z dodajanjem četrte. Zaporedne faze, s hipotetično četrto, je mogoče opredeliti takole:

- od predindustrijske časovno-prostorske povezanosti doma in (vsega) dela, njune nerazdružljivosti in nerazločljivosti z nizko avtonomijo akterjev, določeno s skupnostno solidarnostjo, ki je vezana na prostorsko in socialno bližino;

- $\mathrm{k}$ industrijski časovno-prostorski ločenosti doma in dela s sidriščno vlogo prostorov plačanega, produktivnega dela in sorazmerno omejeno avtonomijo akterjev, vezano na racionalizacijo »časovnega proračuna«;

- k postindustrijskem časovno-prostorskem prežemanju (razsidriščenju) doma in plačanega dela z relativno visoko avtonomijo akterjev, vezano na tehnološko mediacijo z refleksivnim uravnoteženjem socialne bližine in oddaljenosti;

6 Ni odveč ugotovitev o teoretskem in empirično-raziskovalnem prispevku slovenske prostorske sociologije v zgodnejšem in kasnejšem obdobju "prostorskega obrata"v sociologiji . Študije Zdravka Mlinarja "Ljudje v novem mestu Velenje, 1964/65" in kasnejše študije mest Nova Gorica ter Koper (s sodelavci) so dobri primeri tako raziskovalnih inovacij kot odzivanja na družbene spremembe v prostoru.

7 Koncept razvojne logike družbenih sistemov sta zasnovala H. Teune in Z. Mlinar (1978). Za obravnavo konceptualnih razlik v razvojnih in evolucionističnih teorijah glej v: Dietz in Burns, 1992. Za celovit kritični pregled sodobnega sociološkega evolucionizma, tudi v časovno-prostorski perspektivi, glej v: S. K. Sanderson, 2015. 
- $\mathrm{k}$ pospešenem postindustrijskem časovno-prostorskem prežemanju dela in doma, ne zgolj vezanem na tehnološko mediacijo, temveč v odvisnosti od nje, s sidriščno vlogo združenega bivališča/delovišča, znotraj sfere reprodukcije doma.

Preliminarna domneva, da s časovno-prostorskim združevanjem bivališča in delovišča prehajamo v distinktivno, četrto fazo, ki spominja na prvo (predindustrijsko), omogoča analitični razmislek o klasičnih socioloških dilemah diferenciacije in integracije ali tradicionalne in sodobne solidarnosti v časovno-prostorski perspektivi.

Opisno naravo nove časovne geografije lahko ilustrativno umestimo v pojasnjevalni okvir »sociologije družbenega pospeševanja« Hertmuta Rose in drugih teoretikov hitrosti. Rosa družbeno pospeševanje dramatično opredeli s prežemanjem "samohodnega kolesja tehnoloških pospeškov, pospeševanja družbenih sprememb in pospeševanja tempa življenja« (2014: 45). Povezano, geografsko (aksialno) in sociološko (sferično) tematiziranje časa je, kot utemeljujemo v nadaljevanju, solidna podlaga za razumevanje dediferenciacije sfer doma in dela $\mathrm{v}$ postpandemijskem obdobju.

\section{Dediferenciacija sfer doma in dela na osi čas/prostor}

Najprej gre za filozofsko, tako ontološko kot epistemološko, dilemo o tem, ali je za razumevanje človekove narave ter združevanja ljudi sidriščno delo (npr. pri Marxu) ali dom (npr. pri Heideggerju) in ali je »kolonizacija življenjska sveta $\mathrm{z}$ instrumentalno racionalnostjo neizogibna (npr. pri Habermasu). Je za posameznika in družbeno organiziranost primarno osvobojeno, neodtujeno delo ali zakoreninjenost v (pre)bivanju? Bi ponovno podomačenje vsega dela, ko to ne bi bilo več primarna menjalna dejavnost, temveč del avtentičnega ustvarjanja doma z elementi vzajemnosti, kroženja in prerazporejanja nalog znotraj gospodinjstva, zbližalo materialistične in fenomenološke poglede? ${ }^{8}$ Ta dilema je, kot smo že nakazali, implicitno predstavljala izhodišče bolj praktičnega, sociološkega pojasnjevanja tradicionalnih in modernih tipov vzajemnosti oz. solidarnosti, že ob nastanku discipline (npr. pri Durkheimu). Sedanji akutni pandemični pojav ponuja priložnost za izostreno preverjanje, če popolna tehnološka mediacija z odpravo časovno-prostorskega trenja res vzdržno omogoča sodobno, emancipirano podomačenje dela, ne da bi se vrnili v preteklost domačijske avtarkije. $\mathrm{V}$ pomoč pri razmisleku so lahko (idealnotipska) socialna in prostorska sidrišča življenjskih sfer.

8 Ena odoblik, ki se tudi v povezavi med okoljsko vzdržnim krožnim gospodarstvom in prežemanjem življenjskih sfer pogosto preučuje kot smiselna povezava med domom in delom, je združevanje proizvodnje s potrošnjo (ang. prosumption). 
- Domocentričnost ali osredinjenje življenja na dom ${ }^{9}$ povezujemo s tradicionalnimi, predindustrijskimi oblikami družbenoprostorske integracije homogenih, nediferenciranih življenjskih sfer. Delo je le ena od razsežnosti doma, ki je temeljna za reprodukcijo ontološke varnosti, saj zagotavlja stabilne temelje za rutinizacijo življenja in oblikovanje identitete (Giddens, 1991; Wei in Peters, 2019). Tehnološka mediacija s krčenjem prostora in časa, izražena pa ob pojavu pandemije Covida-19, omogoča preizpraševanje o družbenih posledicah sodobne sidriščnosti tehnologiziranega doma.

- Delocentričnost ali osredinjenje življenja na delo ${ }^{10}$ povezujemo $s$ časovno-prostorskim ločevanjem reprodukcijskih sfer od produkcijske sfere v industrijskem kapitalizmu. Delo omogoča reprodukcijo doma v več njegovih razsežnostih (npr. bivanje oz. bivališče). Pri tem je razumevanje doma in dela ter njunega razmerja vezano na temeljna, pozitivistična ali kritična analitična (in moralna) izhodišča o naravi človeka ter družbene strukturiranosti (Land in Taylor, 2010; Khateeb, 2021).

- Tehnocentričnost ali osredinjenje doma in dela s tehnološko mediacijo povezujemo s postindustrijsko socio-tehnično tranzicijo s pospešenim časovno-prostorskim združevanjem reprodukcijske sfere doma $s$ produkcijsko sfero dela. Sidrišče ni ne dom ne delo, temveč vmesnik (»aktant»), ki omogoča izničenje predhodnih, časovno-prostorsko vezanih sidrišč. Tehnologija niso več zgolj pripomočki ali objekti mediacije, temveč pridobiva značaj vitalne entitete avtonomnega delovanja (agency), ki je sokonstitutivna za vse življenjske sfere. Takšno posthumanistično razumevanje je predmet odobravanja in kritik (Latour, 1993; Geels, 2002; Sorrell, 2018; Carrigan in Porpora, 2021).

Zdi se, da po eni strani prožnejša postindustrijska družbena organiziranost na osnovi pospešene omrežne tehnološke mediacije omogoča razreševanje klasične dileme o potencialih afirmativnega združevanja "mehanske in organske solidarnosti«. V tem kontekstu razsrediščenje življenjskih sfer doma in dela z njunim prežemanjem $\mathrm{v}$ precejšnji meri, vsaj v dolgoročnejši perspektivi, rešuje enega osnovnih vidikov v dialektiki nasprotij med individualizacijo in integracijo (Mlinar, 2008a; Putnam in dr., 2016; Migliore in dr., 2021). Optimizem izhaja iz predpostavke, da razsrediščenje

9 Tu se omejujemo na dom kot fizično bivališče (stanovanjsko enoto), čeprav se domocentričnost kot kulturna praksa ukoreninjenosti, avtarkije, pripadnosti, navezanosti ali odvisnosti lahko obravnava na različnih ravneh prostorske organiziranosti: npr. nacionalne. Domocentričnost se lahko navezuje na sedentarnost ali nepripravljenost na selitveno mobilnost (večv Hočevar, 2012).

${ }^{10}$ Mišljeno je plačano delo kot institucionalizirana ekonomska kategorija. Zavedamo se kompleksnosti razmerja med tem in neplačanim ( $n$ pr. gospodinjskim delom, delom otrok, prisilnim delom itd.). Za izčrpno sociološko razpravo o opredelitvah in aktualnih dilemah v zvezi z delom glej v: J. A. Banks, The sociology of work. V: The Frontiers of Sociology (s. 13-27). 
spremlja emancipatorno združevanje ali prežemanje obeh tipov solidarnosti (ali integracije) s pomočjo tehnološke mediacije. Ti procesi naznačujejo dediferenciacijo, desegmentacijo in deinstitucionalizacijo na vseh ravneh časovno-prostorske organizacije družbe. Takšna procesualna dinamika lahko vodi k postopnem sploščenju hierarhičnih razmerij ter krepitvi avtonomnih načinov mrežnega povezovanja v času in prostoru (Hočevar, 2000). Prežemanje lokacij bivanja $\mathrm{z}$ delovnimi prostori ter prožna organizacija časovnih sekvenc potencialno lahko preobrazita prej ločena značaja bivanjskega in delovnega okolja v osvobajajoče, bolj uravnoteženo in manj odtujeno (vse)življenjsko okolje (Mlinar, 2008a). V hipotetičnih, najbolj idealnih okoliščinah bi, na dolgi rok, harmonična prežetost ne samo redefinirala naravo doma in dela, temveč bi odpravila potrebo delitve ter razlikovanja med življenjskimi sferami.

Po drugi strani kritiki tako "z leve« kot »z desne« opozarjajo na omejenosti takšnega dialektičnega naziranja. Baumanovo razumevanje prežemanja sfer s »tekočo moderno", denimo, vsebuje svarilo o tem, da reorganizirana koncentracija kapitala in moči, ki izkorišča fluidnost zgoščenega vmesnega sveta tehnologij, zlahka prevlada nad sicer progresivnimi učinki, ki jo prinaša razsrediščenje sfer (2007, 2017; Lee, 2021).

Sistemsko usmerjeni teoretiki in interpreti te usmeritve z druge perspektive opozarjajo na problematičnost teze o procesih funkcionalne ali segmentarne dediferenciacije. Razsrediščenje lahko povečuje, ne pa nujno zmanjšuje potrebno redukcijo kompleksnosti visoko diferenciranih družb, predvsem z vidika njihove integracije (glej razdelek 3.1). Avtonomija oz. ločenost samoreferenčnih podsistemov zato pogojuje ohranjanje vsaj ohlapne integracije družbe (Tsivacou, 2005; Esposito, 2020). Teoretiki akterjev - omrežij ${ }^{11}$ izpostavljajo naivnost tehnološke utehe pri popolnem preseganju geografskih, časovnih ali institucionalnih meja, saj mreže ljudi in stvari vplivajo drug na drugega, ne le enosmerno, zato omreženosti ne gre zamenjevati z neodvisnostjo in avtonomijo (Latour, 2020).

Problematičnost prežemanja obeh sfer pa, razumljivo, najbolj zaposluje raziskovalce reprodukcije različnih vidikov neenakosti (Land in Taylor, 2010), kar je še posebej očitno zaslediti pri razpravah ob pojavu pandemije Covida-19 (Zhang in dr., 2020). V kritičnih razpravah o prožnem prežemanju obeh sfer so ti avtorji bolj naklonjeni rabi pojma "zamegljevanje«, s čimer poudarjajo izvor novih neenakosti pri obvladovanju ravnotežja med sferami domačega in profesionalnega, zasebnega in javnega ter neformalnega in formalnega (npr. ang. life-work balance, work-life integration, work-life conlict) ${ }^{12}$.

${ }^{11}$ Teorija omrežij-akterjev (ang. Actor-network Theory).

12 Preučevanje teme ravnotežja med delom in zasebnim življenjem (work-life balance - WLB) je že vrsto let samostojna in po količini del že kar nepregledna tema raziskovanja v organizacijskih študijah, 


\section{Časovno-prostorska razsežnost sfer doma (bivališča) in dela (delovišča)}

Besedne zveze "na delu doma«, »v službi doma« ali »nositi delo domov« so že vrsto let lahko običajni in vsakdanji izseki iz nabora praks vsakdanjega življenja ljudi. Lahko pa vsebujejo vse potrebne nastavke za izostreno imaginacijo o preobrazbi družbene organiziranosti v procesu pospešene sociotehnične tranzicije, posebej v časovno-prostorski perspektivi. Pandemija Covida-19 to imaginacijo izostri. Pri usmerjeni obravnavi razmerja med domom in delom izhajamo iz nekaj preprostih postulatov, nato pa jih umestimo v kontekst potencialnih transformacij, s potencialnim pospeševalnim učinkov pandemije Covida-19.

- Prostorska dimenzija doma je bivališče (stanovanje) v bivanjskem okolju (naselje) znotraj družbene enote gospodinjstva (npr. družine).

- Prostorska enota dela je delovišče (delovno mesto) v službenem okolju.

- Časovni dimenziji doma in dela omogočata širši nabor oznak, glede na individualne "časovne proračune« (npr. oddaljenosti/bližine) ter glede interpretativnih izhodišč dihotomij zasebno/javno ali neformalno/formalno (npr. čas za družino, čas za opravke, prosti čas, delovni čas, službeni čas).

- Domače in službeno okolje sta lahko lokacijsko in časovno razporejeni v kontinuumu od popolne ločenosti (samostojnosti) do popolne združenosti (povezanosti) v različnih kombinacijah ali stopnjah njunega časovno-prostorskega prežemanja (npr. solokacije, telelokacije, večsinhronosti).

- Domače in službeno okolje je večrazsežnostno. Razmerja med razsežnostmi je mogoče ponazarjati aksialno, npr. na oseh čas/prostor in sferično, kot npr. prekrivanje, prepletanje ali prežemanje več razsežnosti.

- Kontekst okolij doma je sestavni del spremenjene dinamike časovno-prostorskih poti v prežemanju življenjskih sfer.

V razmerah tržne družbe s plačanim delom omogočamo, vzdržujemo, usklajujemo ali dopolnjujemo reprodukcijo doma, vključno z neplačanim domačim (npr. gospodinjskim) delom. V tem smislu je plačano produktivno delo, ne glede na časovno-prostorski aranžma, sidrno v okviru življenjskih sfer. V razmerah predtržne, "neodtujene« družbe je morda bila - ali morda bo - situacija obrnjena. Dom bi na ta način lahko (ponovno) predstavljal časovno-prostorsko, lahko tudi virtualno sidrno lokacijo (postajo), ki povezuje vse življenjske sfere ali jih celo izniči, tako da jih združi v (vse)življenjsko okolje (Mlinar, 2008a).

Ne glede na vnaprejšnje vrednotno opredeljevanje o sidriščnosti enega

študijah dela, stanovanja, družine, spolov, konstrukcije identitet in na številnih drugih področjih (glej pregled konceptov v: F. R. Khateeb, 2021). 
ali drugega za razumevanje ontologije človekove narave sta dom in delo v vsakem primeru mikro-/makropresečišči med aktivnostmi, relacijami, identitetami, čustvi, kulturo in družbeno strukturo (Mallet, 2004; Boccagni in Kusenbach, 2020). Na dom in delo se torej, ne glede na različna pojasnjevalna izhodišča ali hipotetične scenarije, vežejo distinktivni nabori interakcijskih, komunikacijskih in transakcijskih družbenih praks, ki so umeščeni v vsakokratno materialno okolje in $\mathrm{v}$ časovno razporejanje trajanja, sekvenc ter ritmov (Adam, 2013).

Pandemija Covida-19, kot smo že poudarili, vzpodbudi kritična preizpraševanja klasične Habermasove dileme o kolonizaciji življenjskega sveta v slogu: do kam lahko sega »napadanje domačega prostora skupaj $s » k r a j o$ prostega časa" (Towers in dr., 2006)? ${ }^{13}$ Sedanje »izredne razmere" poudarjeno vzpodbujajo siceršnjo občutljivost za raziskovanje družbene ontologije doma in dela po obdobju prostorske ter časovne ločenosti obeh sfer v industrijskem obdobju. Nekateri avtorji namigujejo, da "je zdaj pravi čas" tudi za ponovni kritični razmislek o epistemološki podlagi obeh ključnih življenjskih sfer, tako z vidika njune ločenosti in združevanja kot v vlogi mehanizmov njune tehnološke mediacije (Biagi, 2020; Lee, 2021).

Pri tem gre, kot smo prikazali v predhodnih razdelkih, za specifično naslavljanje splošnejše konceptualne dileme o mehanizmih diferenciacije in integracije družbe $\mathrm{v}$ razmerah pospešene tehnološke mediacije. Na eni skrajnosti je tehnološki determinizem, ki predvideva popolno nadomestljivost časa in fizičnega prostora $z$ (oddaljenimi) komunikacijami in transakcijami. Vmes je kritični realizem, ki na daljši rok predvideva uravnoteženo komplementarnost tehnološke mediacije s (soprisotnimi) interakcijami med akterji (Hess, 2015). Na drugi skrajnosti je distopični pesimizem, ki predvideva nadvlado tehnologije nad človekom. Prežemanje, hibridizacija, zabrisovanje meja, intersekcija družbenih domen in podobni pojmi so lahko ilustrativni označevalci v pristopih "srednjega dometa«. Ti pojmi pa lahko naznačujejo tudi bolj temeljno pojasnjevalno logiko v naziranju pospešene dinamike diferenciacije in integracije dveh življenjskih sfer: doma (bivališča) in plačanega dela (službe).

Glede na predhodno identifikacijo dveh okvirnih perspektiv pri naslavljanju dediferenciacije življenjskih sfer v sociologiji, sistemske in neo-durkheimovske ter ene $\mathrm{v}$ geografiji časa, lahko sedaj v grobem identificiramo štiri sociološke pristope, $v$ tematiziranju transformacije sfer doma in dela, ki izhajajo iz različnih klasičnih teoretskih tradicij: ${ }^{14}$

13 Tu se ne dotikamo vidikov sociologije dela in organizacij, kjer se v zvezi s "problematičnim « razmer jem delo/dom (služba/prosti čas) postavlja npr. vprašanje "nositi delo na dom«.

14 Pristopi so, po analogiji z življenjskimi sferami, propustni. Nekateri navedeni avtorji se medsebojno - tako afirmativno kot kritiško - medsebojno referirajo. Npr. Z. Baumana lahko uvrstimo v strukturni in eklektični pristop, Z. Mlinarja pa v sistemski pristop. 
- sistemski pristop: združevanje ali prežemanje sfer doma in dela ima svoje meje, ker je avtonomija ene sfere pogojena z obstojem oz. z razlikovanjem druge; njuna vzajemna odvisnost in diferenciranost je pogoj družbene kompleksnosti, temelječe na ohranjanju mozaika različnih racionalnosti (ang. sphere specific rationalities); dediferenciacija je $\mathrm{v}$ osnovi "patološki« ali retrogradni proces in vodi v homogeno družbeno integracijo (West, 2007; Esposito, 2020; Knoblauch in Löw, 2020);

- strukturni pristop: vsaka trajnejša sprememba v delitvi dela vključuje spremembe v delitvi moči; združevanje ali prežemanje sfer doma in dela transformira ter ukinja predhodne ali ustvarja nove oblike neenakosti s pretresi institucionalnega normativnega reda, zlasti distributivnih aranžmajev javnih politik; destrukturiranje časovne in prostorske normativnosti vodi v konfliktno zamegljevanje družbenih vlog; domestikacija ali »utapljanje« javne sfere v zasebno krepi tradicionalne, regresivne oblike solidarnosti (Rosa, 2014; Bauman, 2017; Schmidt, 2020);

- razvojno evolucionistični pristop: dinamični procesi družbenih sprememb vključujejo dialektiko nasprotij diferenciacije in integracije; dediferenciacija življenjskih sfer lahko na krajši rok povzroča razvojna in organizacijska neskladja ali neravnotežja med sferama doma in dela, če gre za enosmernost ali neusklajenost v spremenjenih oblikah integracije med njimi; v daljšem obdobju se vzpostavi konvergenca na spremenjeni, višji razvojni stopnji organiziranja družbe (Alexander, 2018; Mlinar, 1994; Igamberdiev in Brenner, 2020);

- eklektični pristop: sodobni procesi vsakdanjega življenja so konstruirani s kulturnimi praksami znotraj različnih življenjskih slogov, v prežemanju produkcijske »ekonomske baze« in potrošnje »kulturnih praks« (npr. prosumpcija); vzpostavlja se prožno prehajanje med vertikalno in horizontalno diferenciacijo, kar pogojuje propustnost meja sfer doma in dela, kjer je vsaka lahko vsebovana $\mathrm{v}$ vseh drugih; kulturne distinkcije niso nujno vezane na segmentarno in funkcionalno diferenciacijo (Lash in Urry, 1993; Ritzer in Rey, 2016; Wang, 2020).

Ob izhodiščnem vprašanju dialektike avtonomija/povezovanje pri ločevanju/povezanosti sfer doma/dela je za uokvirjanje teze o protislovnih učinkih procesa dediferenciacije ključno še vprašanje o zasebnem/javnem. V kolikšni meri torej dom ostaja v domeni zasebnega življenja, koliko pa institucionalizirana »distribucijska postaja« za sobivanje z zadevami javnega življenja?

\section{Domestikacija dela in podružbljanje doma}

Kako umestiti izvorno analitično dihotomijo zasebne in javne sfere, ki je $\mathrm{v}$ sodobnosti zamenjana $\mathrm{z}$ načelom kontinuuma, $\mathrm{v}$ povezavo med domom in delom? Dediferenciacija zasebne sfere bivanja in javne sfere plačanega 
dela je sicer sorazmerno pogosto del specializiranih raziskovalnih usmeritev v družboslovju; v sociologiji stanovanja (Doling in Arundel, 2020), sociologiji dela in spolov (Felstead in Jewson, 2002) urbani geografiji (Janelle, 1993) in komunikacijskih študijah (Susen, 2011), če navedemo le nekatere. ${ }^{15}$ $\mathrm{V}$ pomembnem delu raziskovanja gre za že prej omenjeno bodisi afirmativno bodisi kritično usmerjeno obravnavo problematike (ne)uravnoteženosti plačanega dela in zasebnega življenja. Avtorji se na eni strani osredotočajo na različne strategije prilagajanja in reorganizacije prostorov in časa ter interakcij in komuniciranja $\mathrm{v}$ smeri podomačenja dela ali podružbljanja doma. Na drugi strani so avtorji, ki $v$ vdiranju dela $v$ sfero doma razkrivajo nove pojavne oblike neenakosti, med katerimi izstopa problematično prekrivanje družbenih vlog (npr. spolnih). Pri tem je značilno razpravljanje o tem, da bodo posamezniki izgubili nadzor nad »svojim" prostorom, pridobili pa bodo več nadzora nad »svojim « časom, katerega upravljanje bo sicer postajalo vse bolj zapleteno in problematično (Lee, 2021). Zelo malo pa je analitičnih razprav, v katerih bi avtorji problematiko (ne)uravnoteženosti umeščali v dolgoročnejšo procesualno logiko sprememb z vidika diferenciacije in integracije ali avtonomije in povezovanja, ki ga (lahko) povzroča trajnejši trend združevanja bivanja in dela.

734 Zapleteno in dvoumno medsebojno delovanje zasebnega in javnega $\mathrm{v}$ razmerah pospešene tehnološke mediacije ne spremeni dejstva, da dom ne pomeni samo specifičnega prostorskega (grajenega) okolja, temveč tudi družbeno (relacijsko) okolje. Enako velja v obratno smer. Prevlada ali izpostavljenost enega nad drugim lahko zamaje osnovno načelo "organske» solidarnosti, ki temelji na povezovanju raznovrstnosti. Epizodni pojav pandemije Covida-19 zelo nazorno uprizori prostorske in družbene razsežnosti dediferenciacije sfer doma in dela. Človekova telesnost je še vedno vezana na fizično umeščenost, tudi če je statična in na enem mestu, denimo v bivališču. V bivališču in ob njem se vzpostavljajo smiselni družbeni odnosi, ki so podlaga vsakršne opredelitve doma. Bivanjska okolja se po svoji kompleksnosti značilno razlikujejo od običajno bolj formaliziranih nebivanjskih okolij delovišč, zato je popolna zamenljivost v obe smeri redka, čeprav ni nemogoča. Ni presenetljivo, da se bistveno več študij posveča prilagajanju bivanjskih prostorov delu na domu kot obratno, to je prebivanju na delovnem mestu. »Domovanje v službi« je še vedno bolj prispodoba za preobremenjenost $\mathrm{z}$ delom $\mathrm{v}$ zvezi $\mathrm{z}$ neuravnoteženostjo domačega življenja kot pa realistična možnost zamenljivosti sfer z načelom »službovati doma».

${ }^{15}$ Kompleksnost prežemanja javne in zasebne sfere je seveda predmet različnih interpretacij. Za oceno Habermasove perspektive v kontekstu »kolonizacije življenjskega sveta« med pandemijo Covida-19 glej M. Thornton, 2021 
Zaradi osredotočenosti na razsežnosti časa in prostora tu niti ne posegamo v temeljne dileme spoznavanja in bit(nosti) niti se ne poglabljamo v specializirane subdisciplinarne poudarke o javnosti ali zasebnosti obeh sfer. Izhajamo zgolj iz osnovne ugotovitve, ki je skupna večjemu, tako afirmativnemu kot kritičnemu delu akademskega tematiziranja in empiričnega raziskovanja tematike. Z našim pojmovnim instrumentarijem lahko ugotovitev strnemo takole: domicil zasebnega in javnega je v kontekstu tehnološke mediacije družbenih razmerij ob pospešeni sociotehnični tranziciji zamegljen in zanikan. Zato binarna poenostavitev, da dom sodi v zasebno, delo pa v javno sfero življenja ne more biti (več) smiselno izhodišče. Od tu naprej je soglasje manjše. Tu navajamo enega bolj nazornih primerov tematiziranja zasebnosti in javnosti v časovno-prostorski perspektivi, ki ga je podal Zdravko Mlinar:

\section{Svojo pozornost za javno/skupno in zasebno/individualno lahko dife- rencirano in povezano upoštevamo glede na prostore in zadeve. Na splošno pričakujemo, da bodo javne zadeve obravnavane v javnih pro- storih in zasebne zadeve $v$ zasebnih prostorih. Toda v kontekstu infor- macijske dobe terjajo posebno pozornost ravno odstopanja od tega ustaljenega reda. ... Javne zadeve in delovanja postajajo zmeraj bolj raznovrstne, tako po vsebini kot po številu udeležencev ter po prostoru in času njihovega pojavljanja ... (Z. Mlinar, 2008b: 57)}

Združevanje sfer pri obravnavi zasebnega in javnega, kot ju oriše Mlinar, vsaj implicitno predpostavlja neproblematično, uravnoteženo in dinamično odstopanje od ustaljenega reda v obe smeri na časovno-prostorski osi. Zadeve (aktivnosti) je v splošnem mogoče razporejati kjerkoli in kadarkoli, ker sta prostor in čas s pomočjo tehnoloških vmesnikov prožna vira v prehajanju iz fizičnih poti v virtualni prostor in iz geografskega v digitalni čas. Ko odstopanja od ustaljenega reda sčasoma pridobijo zagon in postanejo del družbenega reda, sidrišča življenjskih sfer izgubljajo praktično in pojasnjevalno težo. Navedeni oris obenem dobro ponazori okvirno regularnost dediferenciacije življenjskih sfer doma in dela. Domestikacija dela in podružbljanje doma je manifestacija logike emancipirane domačnosti brez vračanja v preteklost domačijske avtarkije, ne da bi bilo ogroženo svetovljansko podružbljanje. Tako tudi idealnotipske prakse delocentričnosti, domocentičnosti in tehnocentričnosti, vezane na stopnjo časovno-prostorskega trenja v historičnih obdobjih modernosti, ne bi imele večje pojasnjevalne teže.

Neskladja in protislovnosti v prežemanju sfer, tudi z refleksijo izredne epizode pandemije Covida-19, v odstopanju od procesualne regularnosti, razumemo kot priložnost za korekcijo evolucionistično razvojnega pristopa pri pojasnjevanju dialektike diferenciacije in integracije, iz katerega v tej razpravi sicer izhajamo. 


\section{Nasprotnosmerne teženje ob dediferenciaciji sfer doma in dela: domocentričnost po pandemiji Covida-19}

V uvodu tega članka smo nakazali, da pospešek časovno-prostorske reorganizacije praks vsakdanjega življenja razumemo kot sodobno vprašanje klasične dileme o mehanizmih družbene solidarnosti v procesu družbene preobrazbe. Temeljne mehanizme in procese spreminjanja opazujemo s perspektive dinamike med diferenciacijo ter integracijo življenjskih sfer na osi čas/prostor. Evolucionistično razvojni pristop po našem prepričanju v splošnem, vendar ne v celoti, omogoča najbolj prepričljivo kontekstualizacijo specifičnih, organizacijskih manifestacij časovno-prostorskih praks v kontekstu procesualne regularnosti družbene preobrazbe in/ali razvoja. Dediferenciacijo življenjskih sfer doma in dela umešča v spremenjeno dinamiko ločevanja in združevanja sidrišč družbenih razmerij v poteku modernizacije družbe. Domocentričnost je značilno časovno-prostorsko sidrišče predmoderne solidarnosti oz. integracije. Delocentričnost sodi v obdobje industrijske modernosti, kjer je produktivno in plačano delo v ločenih prostorih in z ločenimi urniki določujoče (sidriščno) za reprodukcijo doma. Tehnocentričnost je značilnost postindustrijske družbe, kjer je sidrišče, ki

736 omogoča združitev doma in dela, tehnološki vmesnik z odpravo časovno-prostorskih ovir v dostopnosti. V dosedanji razpravi smo skušali pokazati, da prežemanje sidrišč najbolje pojasni procesualni mehanizem dediferenciacije znotraj splošnejšega vzajemnega procesa diferenciacije in integracije. Prežemanje sidrišč v dolgoročni perspektivi (z značilnimi nihanji) naznačuje njihovo odpravo.

Teza o dediferenciaciji sfer doma in dela z vidika organizacije časa in prostora je torej utemeljena na evolutivni oz. razvojni logiki slabitve ovir s tehnološko mediacijo pri osamosvajanju in povezovanju življenjskih sfer zasebnega in javnega. Če je bilo ločevanje sfer doma in dela cena industrijske modernizacije, je proces njunega ponovnega združevanja v teku, mišljen kot razvojni preskok k uravnoteženi integraciji raznovrstnosti s preseganjem, tako mehanske kot organske solidarnosti. Kritična nasprotovanja tej tezi (Eckhardt in Bardhi, 2020) so do določene mere upravičena, vendar pa so po našem prepričanju bolj parcialna in anekdotična. Kot smo $\mathrm{v}$ dosedanji razpravi prikazali s pregledom konceptualnih perspektiv o dediferenciaciji, nasprotovanja ne izvirajo iz zanikanja tega procesualnega mehanizma. Kritike se predvsem nanašajo na neupoštevanje strukturnih (ali sistemskih) konstant s proizvajanjem novih oblik neenakosti in nekompatibilnosti stališča o dediferenciaciji kot razvojnem kazalcu integracije brez sidrišč (Ritzer in Rey, 2016).

Tovrstna nasprotovanja so seveda izziv za premislek o modifikaciji oz. dopolnitvi osnovnih argumentov, ne da bi opustili izhodiščni pojasnjevalni 
okvir. Naš dodaten, če ne ključni izziv modifikacije osnovnega argumenta je refleksija ob pandemiji Covida-19. Predpostavka, da vse manjša določljivost sidrišč doma in dela temelji na časovno-prostorsko neobčutljivi tehnološki mediaciji, ki krepi progresivno regularnost sociotehnične tranzicije k prežemanju sidrišč, se vsaj v luči dolgotrajnejših učinkov pandemije izkazuje v nasprotnosmernosti, kot integracijska regresija. Glede na nejasnost v kolikšni meri lahko ta emergentni pojav pospeši, upočasni ali celo preusmeri evolucijsko razvojni tok v prežemanju življenjskih sfer, je smiselno opozoriti na nekatere manifestacije časovno-prostorskih praks $\mathrm{v}$ teku pandemije Covida-19, ki lahko privzamejo lastnost novih rutin in normativnosti. Ta opozorila obenem predstavljajo preliminarno podlago za modifikacijo evolucionistično razvojne razlage dediferenciacije življenjskih sfer doma in dela.

- Pandemija »zaustavi« značilno procesualno regularnost od industrijske modernosti naprej. Najprej je potekal proces »krčenja prostora s časom", to je nenehno zmanjševanje prostorskih (geografskih) ovir pri povezovanju. Sledila je konvergenca ali krčenje obeh, tako časa kot prostora, kar zaznamuje postindustrijsko modernost v teku.

- Ob pandemiji se soočamo s »krčenjem časa s prostorom«, to je »zabubljenosti« na eni lokaciji kot postaji za distribucijo časa. Sedanja institucionalizirana časovno-prostorska regulacija (vključno s samoregulacijo) z ukrepi osamitve, prepovedi oddaljevanja, fizičnega približevanja ter teritorialnega zamejevanja je situacijska in začasna.

- Ob trajnejši, rutinizirani zaustavitvi premikanja v fizičnem prostoru in ob asistenci tehnoloških vmesnikov so vse sfere povezovanja stisnjene v fizični "zabojnik« bivališča v družbeni enoti gospodinjstva. Avtonomno upravljanje z zasebnimi in javnimi zadevami bi bilo vezano na razporejanje časa doma. Prostorsko naslavljanje vprašanja, »kje« je nekaj ali kdo, bi se okrepljeno nanašalo na telesno gibanje znotraj ene fizične mikrolokacije, s prevlado časovnega naslavljanja vprašanj »kdaj« v zvezi s »čim《 in »kako«. Okrepljena tehnološka mediacija bi ob takem poteku potencialno krepila sidriščno sfero doma - domocentričnost.

- Krepitev že vzpostavljene ali vračanje k domocentričnosti ne pomeni le mehanike organiziranja dejavnosti v kontekstu upravljanja s časovno-prostorskimi potmi. Domocentričnost zadeva vprašanje homo- ali heteronomnega osmišljanja življenjskih sfer (javno/zasebno, formalno/ neformalno), strnjenih znotraj ali razpršenih zunaj bivanjske sfere doma. Ob začasni ujetosti v eno sidrišče je vredno razmisliti o potencialni rutinizaciji te prakse, ki se nagiba $\mathrm{v}$ obratno smer - $\mathrm{k}$ regresiji avtonomije in povezovanja.

- Regresija avtonomije in povezovanja na osi čas/prostor se lahko manifestira v stagnaciji družbenega razvoja v obliki retrogradnih procesov, kot so: krepitev bivanjsko-lastniškega posedovanja namesto usmerjenosti k 
deljenemu dostopu in rabi po potrebi; slabitvi bivanjske in drugih mobilnosti s sedentarnim načinom življenja; slabitev že dosežene ravni spolne ter medgeneracijske enakopravnosti v partnerstvih, družini ali gospodinjstvu; krepitev konfliktov kot posledice zmanjševanja ravnotežja med delom in zasebnim življenjem; retradicionalizacija družine zaradi deinstitucionalizacije vzgoje in izobraževanja; regresija k sedentarnosti namesto mobilnosti in fizičnega gibanja ter soprisotnih interakcij zunaj doma; zamiranje participacije $\mathrm{v}$ javni sferi ("zaton javnega življenja»), ki predstavlja nevarnost demokraciji.

\section{Sklep}

V večjem delu konceptualno usmerjenih družboslovnih razprav o pandemiji Covida-19 avtorji soglašajo, da je pojav tesno povezan s številnimi procesi sprememb in družbene preobrazbe, ki že potekajo in se gibljejo $\mathrm{v}$ določenih smereh. Značilna razlika med njimi je, da eni za izhodišče postavljajo domnevo o začasnem ali trajnejšem zastoju v dolgoročni regularnosti procesov preobrazbe, drugi pa pojavu pripisujejo pospeševalno težo preobrazbe. Ta članek sodi k tistim, ki pojavu pripisujejo pospeševalno težo,

$\mathbf{7 3 8} \mathrm{s}$ preliminarno modifikacijo o možnosti trajnejše regresije $\mathrm{v}$ regularnosti razvoja.

Temeljna podlaga tega konceptualnega članka je klasična sociološka dilema diferenciacije in integracije $\mathrm{v}$ časovno-prostorski perspektivi. Zanimalo nas je, kako se evolutivno spreminja organizacija življenjskih sfer bivanja (doma) in dela (delovnega mesta) z vidika vsakodnevnih praks pod vplivom markantnega epizodnega pojava Covid-19. V analizi smo potrdili domnevo, da pandemija Covida-19 ob izraziti tehnološki mediaciji potencialno pospeši proces dediferenciacije obeh sfer z možnostmi regresivnih in retrogradnih učinkov, ki so lahko tudi trajnejši. Proces dediferenciacije smo opredelili kot premike $\mathrm{k}$ razsidriščenju, prežemanju in prekrivanju življenjskih sfer pod vplivom »časovno-prostorskega krčenja« oz. »konvergence časa in prostora«. Izpostavili smo protislovne učinke tega procesa za sodobno družbeno integracijo v času pandemije, zlasti problematično vzpostavljanje doma kot homogenega sidrišča vseh aktivnosti na osi čas/prostor. Manifestacija sidriščnosti doma je domocentričnost, ki jo sicer povezujemo s tradicionalnimi, predindustrijskimi oblikami družbenoprostorske integracije homogenih, nediferenciranih življenjskih sfer. Delo je tako le ena od reproduktivnih razsežnosti doma. Te premike smo obravnavali kot potencialno retrogradne in regresivne, zlasti v kontekstu ponovnega vzpostavljanja tradicionalnih vlog v gospodinjstvu ter povečevanja neskladnosti ravnotežja med delom in nedelom. Sekundarna ugotovitev, ki izhaja iz temeljne domneve, je, da se ob pandemiji soočamo s »krčenjem časa s prostorom«, to 
je ujetostjo na eni lokaciji kot postaji za distribucijo časa. Sedanjo popolno prežemanje življenjskih sfer doma in dela, ki je sicer že vgrajena v procesualno logiko preobrazbe, smo opredelili s problematično domestikacijo dela in podružbljanjem doma.

V razpravi smo povezovali deskriptivno naravo geografije časa $\mathrm{z}$ analitičnim, bolj abstraktnim zajemanjem evolucionistično razvojnih procesov diferenciacije (osamosvajanja) in integracije (povezovanja) v sociologiji. Tako smo časovno-prostorske poti ponazorili aksialno, na oseh čas/prostor, in sferično, kot so njihovo ločevanje, prekrivanje ali prežemanje. Naslanjali smo se tudi na koncept sociotehnične tranzicije, ki informacijski in telekomunikacijski tehnologiji pripisuje več kot zgolj mediacijsko vlogo med "živimi« akterji in »tehničnimi« omrežji, tako da ti vse bolj pridobivajo značaj "aktantov«, to je samodejnih deležnikov družbene preobrazbe.

Predvidevanje ali nejasnost, v kolikšni meri lahko epizodni pojav pandemije Covida-19 rutinizira in tako pospeši ali zavre evolucijsko razvojni tok v prežemanju življenjskih sfer doma in dela, je lahko zgolj preliminarno. Potrditev osnovne in sekundarne domneve zahteva nadaljnje raziskovanje in empirične poizvedbe s časovno "postpandemijsko« distanco.

\section{LITERATURA}

Adam, Barabara (2013): Timewatch: The social analysis of time. John Wiley \& Sons.

Alexander, Jeffrey C. (2018): The societalization of social problems: Church pedophilia, phone hacking, and the financial crisis. American Sociological Review 83 (6): 1049-1078.

Avelino, Flor, Jan Rotmans (2009): Power in transition: an interdisciplinary framework to study power in relation to structural change. European Journal of Social Theory 12 (4): 543-569.

Banks, J. A. (2020): The sociology of work. In The Frontiers of Sociology, 13-27. Routledge.

Bauman, Zygmunt (2000): Time and space reunited. Time \& Society 9 (2-3): 171185.

Bauman, Zygmunt (2007): Liquid Fear. Cambridge: Polity.

Bauman, Zygmunt (2017): Retrotopia. Cambridge: Polity.

Beck, Ulrich (1992): Risk Society: Towards a New Modernity. Translated by Ritter, Mark. London: Sage Publications.

Biagi, Francesco (2020): Philosophy and Sociology of Space. In Henri Lefebvre's Critical Theory of Space, 121-184. Palgrave Macmillan, Cham.

Boccagni, Paolo, Margarethe Kusenbach (2020): For a comparative sociology of home: Relationships, cultures, structures. Current Sociology 68 (5): 595-606.

Carrigan, Mark, Douglas V. Porpora (2021): Introduction: Conceptualizing posthuman futures. In Post-Human Futures, 1-22. Routledge.

Castells, Manual (1996): The Rise of the Network Society, Malden.

Dietz, Thomas, Tom. R. Burns (1992): Human agency and the evolutionary dynamics of culture. Acta Sociologica 35 (3): 187-200. 
Doling, John, Rovan Arundel (2020): The Home as Workplace: A Challenge for Housing Research. Housing, Theory and Society, 1-20.

Eckhardt, Giana. M., Fleura Bardhi (2020): The value in de-emphasizing structure in liquidity. Marketing Theory 20 (4): 573-580.

Esposito, Elena (2020): Systemic integration and the need for de-integration in pandemic times. Sociologica 14 (1): 3-20.

Felstead, Alan, Nick Jewson (2002): In work, at home: Towards an understanding of homeworking. Routledge.

Geels, Frank. W. (2002): Technological transitions as evolutionary reconfiguration processes: a multi-level perspective and a case-study. Research policy 31 (8-9): 1257-1274.

Giddens, Anthony (1984): The constitution of society. Cambridge: Polity.

Giddens, Anthony (1991): Modernity and Self-Identity: Self and Society in the Modern Age. Polity Books, Cambridge.

Giri, Antana K. (2011): Sociology as Perennial Seeking: Walking with the Inspiring Hands of SN Eisenstadt. Review of Development and Change 16 (2): 247-253.

Hägerstrand, Toersten (1970): "What about people in regional science?". Papers of the Regional Science Association 24 (1): 6-21.

Harvey, David (1990): The condition of postmodernity. Cambridge, MA and Oxford, UK: Blackwell.

Hess, David J. (2015): Power, Ideology, and Technological Determinism. Engaging Science, Technology, and Society 1: 121-125.

Hočevar, Marjan (2000): Novi urbani trendi: omrežja med mesti; prizorišča v mestih. Založba FDV.

Hočevar, Marjan (2012): Dispersed settlement in detached houses: Attitudes over the residential space consumption in Slovenia. Sociologija 54 (1): 123-152.

Hočevar, Marjan (2018): Problem prostorsko okoljske trajnostnosti v razmerah naraščajoče fluidnosti družbenih razmerij. Družboslovne razprave 34 (89): 7-17.

Hočevar, Marjan, Tomaž Bartol (2021): Mapping urban tourism issues: analysis of research perspectives through the lens of network visualization. International Journal of Tourism Cities.

Igamberdiev, Abir U., Joseph. E. Brenner (2020): The evolutionary dynamics of social systems via reflexive transformation of external reality. Biosystems 197: 104219.

Janelle, D. G. (1993): Urban social behavior in time and space. Social Geography of Canadian Cities, 103-118.

Khateeb, Fatima. R. (2021): Work Life Balance - A Review Of Theories, Definitions And Policies. CrossCultural Management Journal (1): 27-55.

Knoblauch, Hubert, Martina Löw (2020): The re-figuration of spaces and refigured modernity-concept and diagnosis. Historical Social Research/Historische Sozialforschung 45 (2): 263-292.

Lash, Scott. M., John Urry (1993): Economies of signs and space (26). Sage.

Latour, Bruno (1993): We have never been modern. Cambridge MA: Harvard University Press. 
Lee, Raymond. L. (2021): Time, space, and power in digital modernity: From liquid to solid control. Time \& Society, 0961463X211016781.

Luhmann, Niklas (1995): Social systems. Stanford University Press.

Mallett, Shelley (2004): Understanding home: a critical review of the literature. The sociological review 52 (1): 62-89.

Merriman, Peter (2012): Human geography without time-space 1. Transactions of the Institute of British Geographers 37 (1): 13-27.

Meynhardt, Timo (2021): The common good on the move: The pandemic as a catalyst.

Migliore Allesandra, Ceinar Irene M., Tagliaro Chiara (2021): Beyond Coworking: From Flexible to Hybrid Spaces. In: Orel M., Dvouletý O., Ratten V. (eds) The Flexible Workplace. Human Resource Management. Springer.

Mlinar, Z. (2008a): Življenjsko okolje v globalni informacijski dobi: Prostorskočasovna organizacija bivanja.

Mlinar, Zdravko (1994): Individuacija in globalizacija v prostoru (35). Slovenska akademija znanosti in umetnosti.

Mlinar, Zdravko (2003): Teledelo in prostorsko-časovna organizacija bivalnega okolja. Teorija in praksa 40 (6): 1012-1039.

Mlinar, Zdravko (2008b): AB. Arhitektov bilten 38: 177/178.

Mosleh, Wafa. S., Henry Larsen (2020): Fieldworking the relational complexity of organizations. Qualitative Research in Organizations and Management: An International Journal.

Overwijk, Jan (2021): Paradoxes of Rationalisation: Openness and Control in Critical Theory and Luhmann's Systems Theory. Theory, Culture \& Society 38 (1): 127-148.

Park, Robert. K., Ernest. W. Burgess \& Roderick. D. McKenzie (Eds.). (1925): The city. Chicago: University of Chicago Press.

Pires, Álvaro, et al. (2021): Epistemological and empirical challenges of Niklas Luhmann's systems theory: an interview with professors Álvaro Pires and Lukas Sosoe. Revista Direito GV 17 (1).

Porter, Jeremy. R. (2011): Context, location, and space: the continued development of our 'geo-sociological'imaginations. The American Sociologist 42 (4): 288-302.

Putnam, Linda. L., Gail T. Fairhurst, Scott Banghart (2016): Contradictions, dialectics, and paradoxes in organizations: A constitutive approach. Academy of Management Annals 10 (1): 65-171.

Ritzer, George, P. J. Rey (2016): "From 'Solid' Producers and Consumers to 'Liquid' Prosumers”, in Davis, M. (ed.) Liquid Sociology: Metaphor in Zygmunt Bauman's Analysis of Modernity, 157-76. New York: Routledge.

Rosa, Hartmut (2013): Social acceleration: A new theory of modernity. Columbia University Press.

Rosa, Hartmut (2014): From work-life to work-age balance? Acceleration, alienation, and appropriation at the workplace. In The impact of ICT on quality of working life, 43-61. Springer, Dordrecht.

Rosa, Hartmut (2017): De-Synchronization, Dynamic Stabilization, Dispositional Squeeze: The Problem of Temporal Mismatch. In J. Wajcman \& N. Dodd (Eds.), 
The Sociology of Speed: Digital, Organizational, and Social Temporalities, 25-41. Oxford: Oxford University.

Rufino, Annamaria (2020): Systemic Regeneration and Circular Society. Italian Sociological Review 10 (3S): 911A-916.

Rye, Stale A. (2008): Conditions of Connectivity: The Internet and the time-space of distance education in Indonesia. Norges teknisk-naturvitenskapelige universitet, Fakultet for samfunnsvitenskap og teknologiledelse, Geografisk institutt.

Sanderson, Stephen K. (2015): Sociological Evolutionism: II. In Evolutionism and Its Critics, 202-232. Routledge.

Schatzki, Ted (2020): Timespace and the organization of social life. In Time, consumption and everyday life, 35-48. Routledge.

Schlüter, Maja et al. (2019): Capturing emergent phenomena in social-ecological systems. Ecology and Society 24 (3).

Schmidt, Volker. H. (2020): Eight theories of societalization: Toward a theoretically sustainable concept of society. European Journal of Social Theory 23 (3): 411430.

Schwinn, Thomas (2001): Differenzierung ohne Gesellschaft. Umstellung eines soziologischen Konzepts. Weilerswist: Velbrück.

Sheller, Mimi, John Urry (2003): Mobile transformations of public and private life. Theory, culture \& society 20 (3): 107-125.

Sorokin, Pitrim (1943): Sociocultural Causality, Space, Time. A Study of Referential Principles of Sociology and Social Science. Durham, North Carolina: Duke University Press.

Sorrell, Steven (2018): Explaining sociotechnical transitions: a critical realist perspective.

Southerton, D. (2020): Time Pressure: Innovation, Acceleration and the SpeedingUp of Everyday Life. In Time, Consumption and the Coordination of Everyday Life, 69-93. Palgrave Macmillan, London.

Susen, Simon (2011): Critical notes on Habermas's theory of the public sphere. Sociological analysis 5 (1): 37-62.

Terpe, Sylvia (2020): Working with Max Weber's "spheres of life": An actor-centred approach. Journal of Classical Sociology 20 (1): 22-42.

Teune, Henry, Mlinar Zdravko (1978): Developmental Logic of Social Systems. Beverly Hills, Sage.

Thornton, Margaret (2021): Coronavirus and the colonisation of private life. Legalities 1 (1): 44-67.

Tietze, Sussane, Gillian Musson (2002): When "Work" Meets "Home" Temporal flexibility as lived experience. Time \& Society 11 (2-3): 315-334.

Towers, I., L. Duxbury, C. Higgins \& J. Thomas (2006): Time thieves and space invaders: Technology, work and the organization. Journal of Organizational Change Management.

Tsivacou, Ioanna (2005): The ideal of autonomy from the viewpoint of functional differentiation/integration of society. Systems Research and Behavioral Science: The Official Journal of the International Federation for Systems Research 22 (6): 509-524. 
Urry, J. (2000): Sociology beyond societies: Mobilities for the twenty-first century. Routledge.

Wang, Qun (2020): Differentiation and De-differentiation: The Evolving Power Dynamics Between News Industry and Tech Industry. Journalism \& Mass Communication Quarterly 97 (2): 509-527.

Ward, Callum (2020): The annihilation of time by space in the COVID-19 pandemic downturn. Dialogues in Human Geography 10 (2): 191-194.

Wei, Zhao, Michael. A. Peters (2019): "Intelligent capitalism" and the disappearance of labour: Whitherto education?.

Werron, Tobias, Leopold Ringel (2020): Pandemic Practices, Part One. How to Turn "Living Through the COVID-19 Pandemic" into a Heuristic Tool for Sociological Theorizing. Sociologica 14 (2): 55-72.

West, Brad (2007): Dedifferentiation. The Blackwell Encyclopedia of Sociology, $1-2$.

Zhang, Shihang, et al. (2020): A work-life conflict perspective on telework. Transportation Research Part A: Policy and Practice 141: 51-68.

\section{VIRI}

Watts, Jonathan (2020): Bruno Latour: "This is a global catastrophe that has come from within" - Interview. The Observer - Coronavirus. The Guardian, 6. 6. 2020. Dostopno prek https://www.theguardian.com/world/2020/jun/06/brunolatour-coronavirus-gaia-hypothesis-climate-crisis, 20. 5. 2021. 